\title{
PENGARUH HARGA DAN KUALITAS PRODUK TERHADAP KEPUTUSAN PEMBELIAN IKAN HIAS AIR TAWAR PADA TOKO RAHMAT AKUARIUM, PONDOK AREN TANGERANG SELATAN
}

\author{
Dimas Kurniawan, Tukidi* \\ *)Dosen Tetap STIE Bhakti Pembangunan Jakarta \\ Email : tukidialdin65@yahoo.co.id; dimaskurnia999@gmail.com;
}

\begin{abstract}
ABSTRAK
Penelitian ini bertujuan untuk mengetahui Pengaruh Harga, dan Kualitas Produk terhadap Keputusan Pembelian Ikan Hias Air Tawar Pada Toko Rahmat Akuarium, Pondok Aren Tangerang Selatan. Hipotesis yang diajukan adalah (1) terdapat pengaruh yang signifikan antara Harga terhadap Keputusan Pembelian Ikan Hias Pada Toko Rahmat Akuarium Pondok Aren Tangerang Selatan, (2) terdapat pengaruh yang signifikan antara Kualitas Produk terhadap Keputusan Pembelian Ikan Hias Pada Toko Rahmat Akuarium Pondok Aren Tangerang Selatan, (3) terdapat pengaruh yang signifikan antara Harga dan Kualitas Produk secara bersama-sama terhadap Keputusan Pembelian Ikan Hias Pada Toko Rahmat Akuarium Pondok Aren Tangerang Selatan.
\end{abstract}

\section{PENDAHULUAN}

Banyaknya jenis keanekaragaman hayati yang terdapat di Indonesia tentu patut dibanggakan. Salah satunya adalah keanekaragaman spesies ikan hiasnya, baik ikan hias air laut maupun ikan hias air tawar. Dengan iklim Indonesia yang tropis sangat cocok untuk budidaya berbagai jenis ikan hias dan sangat memungkinkan dapat memproduksi berbagai jenis ikan hias setiap tahun. Sumber daya alam yang sangat mendukung dikarenakan sebagian wilayah Indonesia adalah kepulauan tentu sumber air sangat melimpah dan pakan alami ikan yang tentunya masih sangat banyak.

Ikan hias air tawar memiliki daya tarik tersendiri, diantaranya ikan yang mudah didapat, harga yang relatif terjangkau, keindahan akan warna, serta bentuk dan corak yang berbeda dari tiap jenis. Hal ini menjadikan ikan hias air tawar diperdagangkan sebagai komoditas hidup sebagai produk hiburan yang banyak diminati oleh sebagian besar masyarakat karena dapat menempati pasar pada setiap tingkat sosial dan ekonomi masyarakat, tergantung dari jenis dan harga ikan tersebut. kegiatan usaha jual beli ikan hias ini memiliki beberapa keunggulan komparatif, diantaranya dapat diusahakan dalam skala besar maupun kecil atau skala rumah tangga. Perputaran modal pada usaha ini relatif cepat, pengembangan strain baru dapat dilakukan secara individu, dan kegiatan usaha ini dapat memperdayakan masyarakat melalui industri kecil yang bermuara pada ekspor.

Selain itu, minat masyarakat juga cukup tinggi terhadap ikan hias diwilayah Pondok Aren Tangerang-Selatan. Dengan adanya beberapa toko ikan hias yang bisa dijumpai diwilayah Pondok Aren ini, hal ini ditandai dengan beberapa tempat penjualan (pedagang eceran) ikan hias yang dapat dijumpai masyarakat di wilayah Pondok Aren dan sekitarnya, mulai dari yang skala besar sampai yang skala kecil bila dilihat dari luas lokasi atau tempat usaha, begitu juga banyaknya jenis ikan hias dan perlengkapan, kualitas produk yang dijual dan tataruang yang teratur. Tempat-tempat tersebut selalu ramai ketika akhir pekan dan hari libur.

Salah satu toko ikan hias yang cukup terkenal oleh pecinta ikan hias di Pondok Aren ialah Toko Ikan Hias Rahmat Akuarium yang terletak di Kelurahan Pondok Betung, Kecamatan 
Pondok Aren Kota Tangerang-Selatan Provinsi Banten yang telah berdiri sejak tahun 2007. Dimana toko tersebut merupakan toko ikan hias yang cukup lengkap, tidak hanya menjual ikan hias namun menjual berbagai peralatan dan perlengkapan pendukung pemeliharaan ikan seperti menjual pakan ikan, obat-obatan, filtrasi air, aerator, haeter, batu aerasi, aksesoris didalam akuarium (lampu, tanaman hias, kinciran) dan lain sebagainya. hal ini dikarenakan konsumen membutuhkan kepraktisan dalam pembelian, dimana konsumen menginginkan membeli ikan dan perlengkapan pemeliharaannya di satu tempat agar lebih efisien waktu dan biaya dan telah menjadi salah satu toko ikan hias yang lengkap diwilayah tersebut.

Faktor harga merupakan faktor penting yang menjadi pertimbangan konsumen dalam membuat keputusan pembelian pada suatu bisnis. Konsumen menginginkan harga produk yang sesuai dengan kualitas dari produk yang bersangkutan. Penetapan harga oleh pelaku bisnis harus disesuaikan dengan lingkungan dan perubahan yang terjadi. Hal tersebut akan mempengaruhi konsumen sebelum memutuskan pembelian karena konsumen akan mencari tau harga dan akan memilih produk yang sesuai dengan kemampuan membelinya.

Selain faktor harga faktor lainnya yang memiliki peranan dalam pengambilan keputusan pembelian terhadap konsumen yaitu kualitas produk. Dengan berbagai jenis ikan hias yang ada serta perlengkapan pendukung yang lengkap dan memadai tentu kualitas sangat diperhatikan oleh penjual mulai dari jenis, bentuk tubuh ikan, warna corak ikan dan kondisi ikan serta perlengkapan yang bagus dan berkualitas, tentu hal ini akan membuat konsumen tertarik dan merasa puas dengan kualitasnya sehingga akan sangat mempengaruhi keputusan pembelian.

Memang harga dan kualitas produk menjadi faktor pemicu konsumen untuk membeli produk suatu perusahaan. Perbedaan harga dan kualitas suatu produk dibawah atau diatas dari pesaing bisnis yang sama merupakan strategi perusahaan untuk menguasai pangsa pasar.

Namun hingga saat ini Toko Ikan Hias Air Tawar Rahmat Akuarium tersebut masih kurang bahkan tidak mengetahui karakteristik konsumen yang datang ke tempat tersebut dan apa saja hal-hal yang dapat mempengaruhi konsumen berbelanja ditempat tersebut, sehingga pemilik merasa kesulitan dalam mengambil kebijakan yang tepat dalam upaya mengembangkan usaha, mempertahankan pelanggan dan menarik konsumen baru.

Berdasarkan latar belakang di atas maka, penulis tertarik untuk memilih judul penelitian mengenai "Pengaruh Harga dan Kualitas Produk Terhadap Keputusan Pembelian Ikan Hias Air Tawar Pada Toko Rahmat Akuarium, Pondok Aren Tangerang Selatan“.

\section{LANDASAN TEORI}

\section{Harga}

Harga produk atau jasa yang dipasarkan merupakan faktor yang sangat penting.. Persaingan harga sangat mempengaruhi bertahan atau tidaknya suatu perusahaan menghadapi para pesaingnya. Menurut Kotler \& Amstrong (2012), harga merupakan sejumlah uang yang dibebankan atas suatu produk atau jasa atau jumlah dari nilai yang ditukar konsumen atas manfaat-manfaat karena memiliki atau menggunakan produk atau jasa tersebut.

Harga memiliki peranan utama dalam proses pengambilan keputusan (Tjiptono.2009) yaitu :

1) Peranan alokasi harga

2) Peranan informasi harga

Ada beberapa metode dasar yang digunakan untuk penetapan harga, yaitu:

1) Harga yang didasarkan pada biaya

(a) Metode Cost-Plus Pricing

(b) Metode Mark - Up Pricing

2) Analisa Break-Even (pulang pokok) 
Perusahaan dapat dikatakan dalam keadaan break-even bilamana penghasilan (revenue) yang diterima sama dengan ongkosnya, dengan anggapan bahwa harga jualnya sudah tertentu. Menurut metode ini, perusahaan akan mendapatkan laba bilamana penjualan yang dicapai berada di atas titik break-even.

3) Analisa Marjinal

Dalam analisa marjinal, harga ditentukan atas dasar keseimbangan antara penawaran dan permintaan. Untuk mendapatkan laba maksimum, penjual/produsen dapat menentukan harga per unit dimana permintaan per unit seimbang dengan biaya per unitnya.

4) Penetapan harga dalam hubungannya dengan pasar

(a) Penetapan harga sama dengan harga saingan.

(b) Penetapan harga di bawah harga saingan

(c) Penetapan harga di atas harga saingan

\section{Kualitas Produk}

Definisi kualitas produk sendiri menurut Kotler dan Armstrong (2012:283), kemampuan sebuah produk dalam memperagakan fungsinya, hal ini termasuk keseluruhan durabilitas, reliabilitas, ketepatan, kemudahan pengoperasian, dan reparasi produk, juga atribut produk lainnya. Terdapat beberapa konsep yang saling berhubungan mengenai kualitas, yaitu :

1) Kualitas objektif atau kualitas yang sebenarnya, yaitu besarnya barang atau jasa menunjukan keunggulan dari produknya kepada konsumen.

2) Kualitas berdasarkan kepada produk, menyangkut sifat dan jumlah dari bahan- bahan penampilan fisik produk termasuk juga layanan.

3) Kualitas dari sudut pandang konsumen (kualitas yang diterima oleh konsumen), merupakan persepsi konsumen mengenai keseluruhan kualitas atau keunggulan produk dihubungkan dengan maksud penggunaanya berikut alternatif-alternatifnya.

Hal ini menunjukan kualitas yang diterima oleh konsumen merupakan konsep yang terpenting

\section{Dimensi Kualitas Produk}

Menurut Kotler \& Keller (2012:283) kualitas produk dapat dimasukan ke dalam 9 dimensi, yaitu :

1) Bentuk (Form)

2) Ciri-ciri produk (Features)

3) Kinerja (Performance)

4) Ketepatan atau kesesuaian (Conforrmance)

5) Ketahanan (durabillity) .

6) Kehandalan (reliabillity) .

7) Kemudahan perbaikan (repairabillity)

8) Gaya (Style)

9) Desain (design) .

\section{Keputusan Pembelian}

Buchari Alma (2011:96) berpendapat bahwa keputusan pembelian sebagai suatu keputusan konsumen yang dipengaruhi oleh ekonomi keuangan, teknologi, politik, budaya, produk, harga, lokasi, promosi, physical evidence, people dan process, sehingga membentuk suatu sikap pada konsumen untuk mengolah segala informasi dan mengambil kesimpulan berupa respon yang muncul produk apa yang akan dibeli. Menurut Kotler dan Keller yang dialih bahasakan oleh Tjiptono (2012:193) keputusan pembelian sebagai tahap keputusan dimana konsumen secara aktual melakukan pembelian suatu produk. 


\section{Dimensi Keputusan Pembelian}

Dimensi dan indikator keputusan pembelian menurut Kotler dan Keller yang dialih bahasakan oleh Tjiptono (2012:184) menjelaskannya bahwa keputusan konsumen untuk melakukan pembelian suatu produk meliputi enam sub-keputusan sebagai berikut:

1) Pilihan produk

2) Pilihan merek

3) Pilihan penyalur

4) Waktu pembelian.

5) Jumlah pembelian

\section{Kerangka Pemikiran}

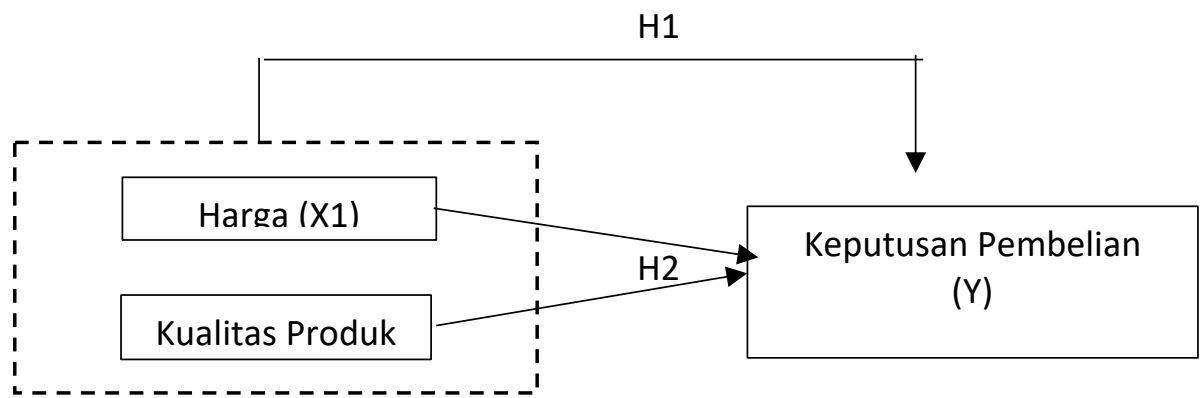

\section{METODE PENELITIAN}

\section{Waktu dan Tempat Penelitian}

Waktu dalam pengumpulan data dalam pembuatan skripsi ini adalah selama lima bulan, terhitung dari bulan Maret - Juli 2019.

\section{Desain Penelitian}

Jenis penelitian ini adalah penelitian Kausal (Causal Research) yaitu penelitian untuk mengetahui pengaruh satu atau lebih variabel bebas (independent variable) terhadap variabel terikat (dependent variable)

\section{Metode Pengumpulan dan Pemilihan Data}

Pengumpulan data merupakan teknik yang bertujuan untuk mendapatkan atau mengumpulkan data (informasi) yang dapat menjelaskan dan atau menjawab permasalahan penelitian yang bersangkutan.Untuk maksud dan tujuan penyusunan skripsi ini, penulis menggunakan beberapa cara pengumpulan data, yaitu :

1) Kuesioner : pengumpulan data dengan responden (sumber data) terjadi wawancara dan tatap muka secara langsung.

2) Observasi : yaitu memperhatikan dengan cara pengumpulan data obyek penelitian secara langsung

3) Studi Kepustakaan : Data ini dapat diperoleh dan dikumpulkan dengan cara membaca bukubuku literatur ilmiah, catatan kuliah, serta sumber data yang berhubungan dengan skripsi yang sedang disusun ini. 
4) Wawancara :Bentuk komunikasi langsung antara peneliti dan responden, yang berlangsung dalam bentuk tanya jawab dalam hubungan tatap muka.

5) Teknik Skoring

Mengubah data yang bersifat kualitatif ke dalam bentuk kuantitatif. Dalam penentuan skor ini digunakan skala likert dengan lima kategori penilaian, yaitu:

\section{Tabel 1}

Skala Likert

\begin{tabular}{|c|c|c|c|}
\hline No & \multicolumn{2}{|c|}{ Kategori Jawaban } & Nilai \\
\hline 1. & Sangat setuju & $(\mathrm{SS})$ & 5 \\
\hline 2. & Setuju & $(\mathrm{S})$ & 4 \\
\hline 3. & Ragu-ragu & $(\mathrm{RR})$ & 3 \\
\hline 4. & Tidak Setuju & ( TS ) & 2 \\
\hline 5. & Sangat Tidak Setuju & ( STS ) & 1 \\
\hline
\end{tabular}

Sumber : Data diolah sendiri

\section{Populasi \& sampel}

Populasi adalah keseluruhan pelanggan atau konsumen yang berkunjung di Toko Ikan Hias Air Tawar Rahmat Akuarium, Tangerang Selatan. Dalam penelitian ini, terdapat 70 orang responden / sampel yang peneliti batasi pada Toko Ikan Hias Air Tawar Rahmat Akuarium Pondok Aren. Pemilihan sempel dalam teknik ini bersifat subyektif hanya berdasarkan penilaian peneliti. Peneliti menggunakan teknik non probability sampling dan yang dipilih adalah accidental sampling, yaitu teknik sampling berdasarkan kebetulan siapa saja konsumen yang bertemu dengan peneliti dapat digunakan sebagai sempel bila dipandang konsumen yang ditemui cocok sebagai sumber data sesuai kriteria yang telah peneliti buat. Dalam hal ini akan lebih dahulu dilakukan perumusan kriteria-kriteria yang digunakan sebagai acuan penarikan sampel. Kriteria konsumen yang dipilih menjadi responden adalah sebagai berikut :

1) Umur responden diatas 14 tahun yang dinilai dapat memberikan jawaban secara objektif.

2) Bersedia diwawancarai dengan panduan kuesioner yang telah disediakan.

3) Dalam satu rombongan atau keluarga hanya diambil satu orang yang menjadi responden agar tidak saling mempengaruhi dalam menjawab kuesioner.

4) Pernah melakukan kunjungan dan pembelian minimal sekali.

\section{Indikator Penelitian}

\section{Harga (X1)}

Indikator yang mencirikan harga yang digunakan dalam penelitian ini, yaitu:

1) Kesesuaian harga dengan kualitas produk

2) Keterjangkauan harga

3) Daya saing harga

4) Kebenaran harga yang tercantum

\section{Kualitas Produk (X2)}

Indikator yang mencirikan kualitas produk yang digunakan dalam penelitian ini, yaitu:

1) Keistimewaan produk

2) Kesesuaian dengan spesifikasi

3) Estetika 


\section{Keputusan Pembelian (Y)}

Indikator yang mencirikan kualitas produk yang digunakan dalam penelitian ini, yaitu:

1) Kebutuhan dan keinginan akan suatu produk

2) Keputusan pembelian ulang

3) Kemantapan akan kualitas suatu produk

4) Harga yang terjangkau

\section{HASIL DAN PEMBAHASAN}

\section{Jenis Kelamin}

Berdasarkan jenis kelamin sebagian besar responden yang datang ke Toko Rahmat Akuarium berjenis kelamin laki-laki sebanyak 51 responden $(85 \%)$ dari total responden, sedangkan untuk jenis kelamin perempuan sebanyak 9 responden (15\%). Segmen pasar Rahmat Akuarium adalah para pencari produk hiburan terutama para pecinta ikan hias baik laki-laki maupun perempuan. Selengkapnya dapat dilihat pada tabel dan diagram pie berikut:

Tabel 2

\section{Karakteristik Responden Berdasarkan Jenis Kelamin}

\begin{tabular}{|c|c|c|}
\hline Jenis Kelamin & Total & Presentase (\%) \\
\hline Laki-laki & 51 & 85 \\
\hline Perempuan & 9 & 15 \\
\hline Jumlah & $\mathbf{6 0}$ & $\mathbf{1 0 0}$ \\
\hline
\end{tabular}

\section{Usia}

Dalam penelitian ini pengelompokan usia dibagi menjadi 4 kelompok usia. Dari hasil penyebaran kuesioner terlihat adanya suatu kelompok usia responden yang sedikit mendominasi. Seperti pada kelompok usia 15-25 tahun sebanyak 23 responden $(38,3 \%)$, usia 26-35 tahun sebanyak 17 reponden (28,3\%), usia 36-45 tahun sebanyak 12 responden (20\%), dan pada usia > 46 tahun sebanyak 8 responden $(13,4 \%)$. Hal ini menandakan produk ikan hias yang ada di Toko Rahmat Akuarium juga digemari oleh kalangan dewasa terkhusus berbagai usia. Sehingga pihak Toko Rahmat Akuarium lebih memperhatikan apa yang di inginkan konsumen pada setiap kelompok usia. Selengkapnya dapat dilihat pada tabel dan diagram pie berikut:

Tabel 3

Karakteristik Responden Berdasarkan Usia

\begin{tabular}{|c|c|c|}
\hline Usia & Total & Presentase (\%) \\
\hline 15-25 Tahun & 23 & 38,3 \\
\hline 26-35 Tahun & 17 & 28,3 \\
\hline 36-45 Tahun & 12 & 20 \\
\hline$>46$ Tahun & 8 & 13,4 \\
\hline Jumlah & $\mathbf{6 0}$ & $\mathbf{1 0 0}$ \\
\hline
\end{tabular}




\section{Tingkat Pendidikan}

Pendidikan yang dimiliki seseorang menunjukan tingkat pengetahuan, wawasan, pola pikir, dan perilaku serta berpengaruh terhadap tindakan yang dilakukan. Semakin tinggi tingkat pendidikan yang dicapai, semakin luas pengetahuan, wawasan, dan pola pikir seseorang sehingga responden akan sangat responsif terhadap informasi.

Terdapat enam kategori tingkat pendidikan teakhir responden Toko Rahmat Akuariumn mulai dari tingkat pendidikan SD hingga Pascasarjana. Secara keseluruhan tingkat pendidikan responden tergolong tinggi yaitu didominasi Sarjana sebanyak 19 responden (31,7\%), Diploma sebanyak 11 responden (18,3\%), Pasca Sarjana sebanyak 4 responden (6,7\%), SMP/MTs sebanyak 9 responden (15\%). Dan untuk tingkat SMU dengan responden sebanyak 17 responden $(28,3 \%)$ dengan sebagian dari responden sedang melanjutkan pendidikan ke perguruan tinggi. Kondisi tersebut memperlihatkan bahwa rata-rata responden memiliki tingkat pendidikan yang cukup tinggi, yang menyebabkan mereka akan berperilaku kritis dalam pembelian sebuah produk. Selengkapnya dapat dilihat pada tabel dan diagram pie berikut:

\section{Tabel 4}

\section{Karakteristik Responden Berdasarkan Pendidikan}

\begin{tabular}{|c|c|c|}
\hline Pendidikan & Total & Presentase $(\%)$ \\
\hline $\mathrm{SD} / \mathrm{MI}$ & 0 & 0 \\
\hline SMP/MTs & 9 & 15 \\
\hline SMU/SMA & 17 & 28,3 \\
\hline Diploma/Sederajat & 11 & 18,3 \\
\hline Sarjana & 19 & 31,7 \\
\hline Pasca Sarjana & 4 & 6,7 \\
\hline Jumlah & 60 & 100 \\
\hline
\end{tabular}

\section{Jenis Pekerjaan}

Bila dilihat pada hasil penelitian pada Tabel 4.4, peminat produk di Toko Rahmat Akuarium cenderung mengarah pada jenis pekerjaan yaitu swasta sebanyak 26 responden $(43,3 \%)$, diikuti oleh mahasiswa/pelajar sebanyak 16 responden $(26,6 \%)$, wiraswasta sebanyak 10 responden $(16,7 \%)$, pegawai negeri sebanyak 4 responden $(6,7 \%)$, ibu rumah tangga atau tidak bekerja sebanyak 3 responden (5\%), dan pekerjaan lainnya sebanyak 1 responden $(1,7 \%)$. Konsumen yang mempunyai pekerjaan tetap (baik di swasta maupun pegawai negeri) tentu akan memiliki penghasilan yang tetap juga, hal itu menunjukkan kemampuan konsumen dalam mendukung penyaluran hobi ikan hiasnya. Selengkapnya dapat dilihat pada tabel dan diagram pie berikut:

Tabel 5

Karakteristik Responden Berdasarkan Pekerjaan

\begin{tabular}{|c|c|c|}
\hline Pekerjaan & Total & Presentase (\%) \\
\hline Mahasiswa/Pelajar & 16 & 26,6 \\
\hline
\end{tabular}




\section{Uji Validitas}

\begin{tabular}{|l|c|c|} 
Pegawai Negeri & 4 & 6,7 \\
\hline Pegawai Swasta & 26 & 43,3 \\
\hline Wiraswasta & 10 & 16,7 \\
\hline IRT & 3 & 5 \\
\hline Lainnya & 1 & 1,7 \\
\hline \multicolumn{1}{|c|}{ Jumlah } & $\mathbf{6 0}$ & $\mathbf{1 0 0}$ \\
\hline
\end{tabular}

Uji Validitas bertujuan untuk mengetahui seberapa cermat suatu item dalam mengukur apa yang ingin diukur (kuisioner)(Priyatno, 2017:63).Hasil yang didapat penulis merupan seluruh pernyataan valid sesuai dengan hasil SPSS penulis yang mana $r$ hitung $>r$ tabel .

\section{Uji Reliabilitas}

Menurut Priyatno (2017:79) Uji reliabilitas digunakan untuk mengetahui keajegan atau konsistensi alat ukur yang biasanya menggunakan kuesioner. Hasil yang didapat penulis merupan seluruh pernyataan Reliabel sesuai dengan hasil SPSS dengan nilai Cronbach Alpha> 0,6 yang berarti reliabel

Dari ketiga variable diatas disimpilkan hasil pengilahan data menggunakan spss dinyatakan valid dan reliabel

\section{Uji Asumsi Klasik}

\section{Uji Normalitas Residual}

Tujuan dilakukannya uji ini adalah untuk menguji apakah dalam sebuah model regresi, variabel independen, variabel dependen, atau keduanya mempunyai distribusi normal atau tidak.

Gambar 1

\section{Grafik Uji Normalitas}

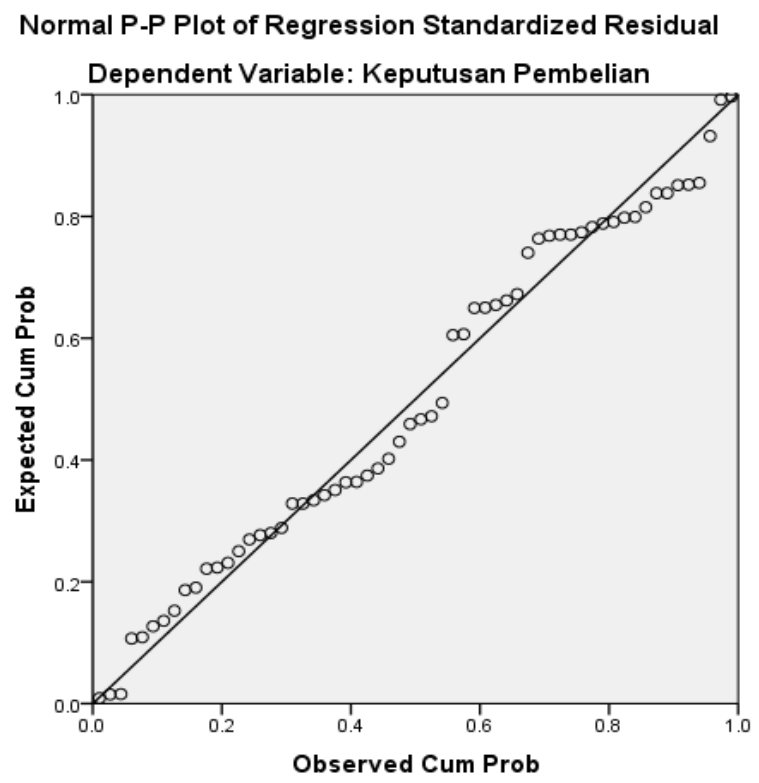

Sumber :Diolah dengan SPSS 23.0 
Berdasarkan gambar 4.9 hasil Uji Normalitas diatas dapat ditarik kesimpulan bahwa data mengikuti distribusi normal. Karena titik-titik disekitar garis adalah menggambarkan keadaan data yang diuji dari titik-titik tersebut mengikuti garis diagonal bahkan menempel pada garis diagonal dan tidak ada tiitk-titik yang jauh dari garis normal.

\section{Uji Multikolinearitas}

Asumsi Multikolinearitas menyatakan bahwa variabel independen harus terbebas dari gejala Multikolinearitas.

Tabel 6

\section{Uji Multikolonieritas}

Coefficients $^{\mathrm{a}}$

\begin{tabular}{|c|c|c|c|c|c|c|c|c|}
\hline \multirow{2}{*}{\multicolumn{2}{|c|}{ Model }} & \multicolumn{2}{|c|}{$\begin{array}{c}\text { Unstandardized } \\
\text { Coefficients }\end{array}$} & \multirow{2}{*}{$\begin{array}{c}\text { Standardized } \\
\text { Coefficients } \\
\text { Beta }\end{array}$} & \multirow[b]{2}{*}{$\mathrm{t}$} & \multirow[b]{2}{*}{ Sig. } & \multicolumn{2}{|c|}{ Collinearity Statistics } \\
\hline & & $\mathrm{B}$ & Std. Error & & & & Tolerance & VIF \\
\hline \multirow[t]{3}{*}{1} & $\begin{array}{l}\text { (Constan } \\
\text { t) }\end{array}$ & 10.342 & 4.115 & & 2.513 & .015 & & \\
\hline & Harga & .460 & .141 & .443 & 3.265 & .002 & .475 & 2.105 \\
\hline & $\begin{array}{l}\text { Kualitas } \\
\text { Produk }\end{array}$ & .273 & .116 & .319 & 2.349 & .022 & .475 & 2.105 \\
\hline
\end{tabular}

a. Dependent Variable: Keputusan Pembelian

Sumber :Diolah dengan SPSS 23.0

Berdasarkan tabel 4.12 diatas menunjukkan variabel bebas menunjukkan nilai tolerance sebesar 0,475 artinya semua variabel bebas memiliki nilai tolerance $>0,10$ artinya tidak terjadi korelasi antara variabel bebas. Hasil Variance Inflation Factor (VIF) menunjukan semua variabel bebas memiliki nilai VIF 2,105 $<10$ artinya tidak ada multikolonieritas antara variabel bebas.

\section{Uji Heteroskedastisitas}

Asumsi ini bertujuan untuk menguji apakah model regresi terjadi ketidaksamaan varience dari residual satu pengamatan ke pengamatan yang lain. Jika variance dari residual satu pengamatan ke pengamatan lain tetap, maka disebut homoskedastisitas dan jika berbeda dengan heteroskedastisitas. Model regresi yang baik adalah yang homoskesdastisitas atau tidak terjadi heteroskedastisitas. Kebanyakan data crosstection mengandung situasi heteroskedastisitas karena data ini menghimpun data yang mewakili berbagai ukuran (kecil, sedang, dan besar). Heteroskedastisitas pada suatu model dapat dilihat dari pola gambar scatterplot.

Untuk mendeteksi adanya heteroskedastisitas dapat dilihat pada grafik Scatteerplot pada gambar dibawah ini:

Gambar 2

\section{Uji Heteroskedastisitas}

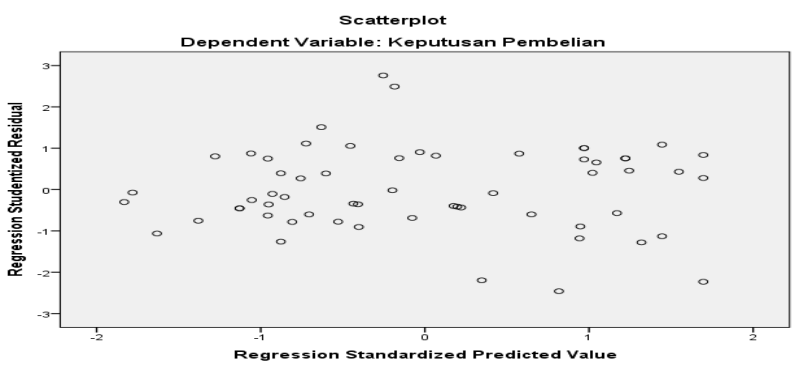

Sumber: Diolah dengan SPSS 23.0 
Berdasarkan gambar 4.10 diatas terlihat bahwa titik-titik menyebar secara acak serta tersebar baik di atas maupun dibawah angka 0 pada sumbu Y. Hal ini dapat disimpulkan bahwa tidak terjadi heteroskedastisitas pada model regresi atau dapat disimpulkan bahwa tidak terjadi ketidaksamaan variance dari residual satu pengamatan ke pengamatan lain, sehingga model regresi layak dipakai untuk memprediksi loyalitas pengguna berdasarkan masukan variabel independen Pengaruh Harga dan Kualitas Produk.

\section{Uji Autokorelasi}

Uji autokorelasi adalah keadaan pada model regresi ada korelasi antara residual pada periode $t$ dengan residual pada periode $\mathrm{t}-1$ (sebelumnya). Model regresi yang baik adalah tidak terdapat masalah autokorelasi. Jika terjadi korelasi, maka dinamakan ada autokorelasi. Model pengujian ini dapat di uji dengan menggunakan uji Durbin Watson (DW test).

Tabel 8

\section{Uji Autokorelasi}

\begin{tabular}{l|r|r|r|r|r|}
\hline Model & $\mathrm{R}$ & $\mathrm{R}$ Square & $\begin{array}{c}\text { Adjusted R } \\
\text { Square }\end{array}$ & $\begin{array}{c}\text { Std. Error of the } \\
\text { Estimate }\end{array}$ & Durbin-Watson \\
\hline 1 & $.709^{\mathrm{a}}$ & .502 & .485 & 3.71070 & 1.727 \\
\hline
\end{tabular}
a. Predictors: (Constant), Kualitas Produk, Harga
b. Dependent Variable: Keputusan Pembelian

Sumber: Diolah dengan SPSS 23.0

Dengan nilai tabel pada tingkat signifikansi $5 \%$ dengan jumlah sampel 60 (n) dan jumlah variabel independent $2(\mathrm{k}=2)$. Nilai Durbin Watson (DW Statistik) dari hasil analisis regresi sebesar 1,727 dan dapat dilihat pada tabel 4.13 diatas. Dengan demikian nilai Durbin Watson tersebut berada pada interval 1,6518 $(1,6518<1,727<2,3482)$, sehingga model regresi linier berganda tersebut tidak terjadi gejala autokorelasi.

\section{Uji Regresi Linear Berganda}

Setelah variabel dianalisis dengan rincian yaitu variabel Pengaruh Harga dan Kualitas Produk sebagai variabel bebas (independent variabel) sedangkan Keputusan Pembelian sebagai variabel terikat (dependent variabel). Kedua variabel tersebut diolah dengan menggunakan analisis regresi berganda pada program SPSS 23. Analisis digunakan bagaimana pengaruh antara. Pengaruh Harga dan Kualitas Produk (variabel bebas) terhadap Keputusan Pembelian (variabel terikat). Toko Ikan Hias Air Tawar Rahmat Akuarium.

Tabel 9

Uji Analisis Regresi Linear Berganda Coefficients $^{\mathrm{a}}$

\begin{tabular}{|c|c|c|c|c|c|c|}
\hline \multirow{2}{*}{\multicolumn{2}{|c|}{ Model }} & \multicolumn{2}{|c|}{ Unstandardized Coefficients } & $\begin{array}{l}\text { Standardized } \\
\text { Coefficients }\end{array}$ & \multirow[b]{2}{*}{$\mathrm{t}$} & \multirow[b]{2}{*}{ Sig. } \\
\hline & & $\mathrm{B}$ & Std. Error & Beta & & \\
\hline \multirow[t]{3}{*}{1} & (Constant) & 10.342 & 4.115 & & 2.513 & .015 \\
\hline & Harga & .460 & .141 & .443 & 3.265 & .002 \\
\hline & $\begin{array}{l}\text { Kualitas } \\
\text { Produk }\end{array}$ & .273 & .116 & .319 & 2.349 & .022 \\
\hline
\end{tabular}

a. Dependent Variable: Keputusan Pembelian

Sumber: Diolah dengan SPSS 23.0 
Berdasarkan tabel 4.14 diatas diperoleh persamaan regresi linear sebagai berikut:

Keterangan :

$$
\begin{gathered}
Y=a+b_{1} X_{1}+b_{2} X_{2} \\
Y=10,432+0,460 X_{1}+0,273 X_{2}
\end{gathered}
$$

$\mathrm{Y} \quad=$ Variabel Terikat (dependent)

a $\quad=$ Nilai konstanta

$\mathrm{b}_{1} \mathrm{~b}_{2}=$ Nilai koefisien regresi

$\mathrm{X}_{1} \mathrm{X}_{2}=$ Variabel bebas (independent)

berikut:

Dari persamaan yang terbentuk diatas dapat dijelaskan interprggesentasinya sebagai

1) Konstanta: 10,342 artinya apabila variabel Pengaruh Harga $\left(\mathrm{X}_{1}\right)$ dan Pengaruh Kualitas Produk $\left(\mathrm{X}_{2}\right)$ dalam keadaan konstan, maka (Y) Keputusan Pembelian adalah sebesar 10,342 satuan.

2) $\mathrm{B} 1=0,460$ artinya apabila variabel Pengaruh Harga $\left(\mathrm{X}_{1}\right)$ dan Kualitas Produk $\left(\mathrm{X}_{2}\right)$ dalam keadaan konstan, maka (Y) Keputusan Pembelian adalah sebesar 0,460 satuan.

3) $\mathrm{B} 2=0,273$ artinya apabila variabel Pengaruh Harga $\left(\mathrm{X}_{1}\right)$ dan Kualitas Produk $\left(\mathrm{X}_{2}\right)$ dalam keadaan konstan, maka (Y) Keputusan Pembelian adalah sebesar 0,273 satuan.

Rumus tersebut menunjukkan apabila Pengaruh Harga dan Pengaruh Kualitas Produk dinaikkan satu-satuan akan meningkatkan Keputusan Pembelian 46\% $(0,460)$ di Pengaruhi Harga dan 27,3\% (0,273) di Pengaruhi Kualitas Produk. Dari tabel diatas dikatakan bahwa jika ada Pengaruh Harga dan Pengaruh Kualitas Produk maka Keputusan Pembelian akan meningkat dan membawa pengaruh positif.

\section{Uji Koefisien Kolerasi}

Nilai Koefisien Korelasi berkisar antara 0 sampai 1 atau 0 sampai -1. Semakin mendekati 1 atau -1 maka hubungan semakin kuat. Jika mendekati 0 maka hubungan semakin lemah.

\section{Tabel 10}

\section{Uji Koefisien Korelasi}

\begin{tabular}{|ll|r|r|r|}
\hline \multicolumn{2}{|c|}{ Correlations } & \multicolumn{2}{c|}{$\begin{array}{c}\text { Keputusan } \\
\text { Pembelian }\end{array}$} \\
\hline Harga & Harga & Kualitas Produk & $.674^{* *}$ \\
& Pearson Correlation & 1 & $.725^{* *}$ & .000 \\
& Sig. (2-tailed) & & .000 & 60 \\
& $\mathrm{~N}$ & 60 & 1 & $.639^{* *}$ \\
\hline Kualitas Produk & Pearson Correlation & $.725^{* *}$ & .000 \\
& Sig. (2-tailed) & .000 & 60 & 60 \\
\hline Keputusan Pembelian & Pearson Correlation & $.674^{* *}$ & $.639^{* *}$ & 1 \\
& Sig. (2-tailed) & .000 & .000 & 60 \\
\hline
\end{tabular}

**. Correlation is significant at the 0.01 level (2-tailed).

Sumber: Diolah dengan SPSS 23.0

Berdasarkan hasil analisis data dengan menggunakan SPSS 23. Person Corelation hubungan antara Pengaruh Harga dan Kualitas Produk terhadap Keputusan Pembelian sebagai berikut:

1) Koefisien korelasi antara Pengaruh Harga $\left(\mathrm{X}_{1}\right)$ terhadap Keputusan Pembelian $(\mathrm{Y})$ sebesar 0,674 berarti keeratan korelasi kuat. 
2) Koefisien korelasi antara Pengaruh Kualitas Produk $\left(\mathrm{X}_{2}\right)$ terhadap Keputusan Pembelian (Y) sebesar 0,639 berarti keeratan korelasi kuat.

\section{Analisis Koefisien Determinasi $\left(\mathbf{R}^{2}\right)$}

Berdasarkan kontribusi variabel independen mempengaruhi variabel dependen dapat diketahui dari nilai koefisien determinasi. Nilai koefisien determinasi atau $\mathrm{R}^{2}$ dapat dilihat dari hasil pengolahan data menggunakan SPSS 23. Pada tabel model summary kolom Adjusted Rsquare sebagai berikut:

Tabel 11

Tabel Determinasi

Model Summary

\begin{tabular}{|l|r|r|r|r|}
\hline Model & R & R Square & \multicolumn{1}{|c|}{$\begin{array}{c}\text { Adjusted R } \\
\text { Square }\end{array}$} & $\begin{array}{c}\text { Std. Error of the } \\
\text { Estimate }\end{array}$ \\
\hline 1 & $.709^{\mathrm{a}}$ & .502 & .485 & 3.71070 \\
\hline
\end{tabular}

a. Predictors: (Constant), Kualitas Produk, Harga

b. Dependent Variable: Keputusan Pembelian

Sumber: Diolah dengan SPSS 23.0

Berdasarkan tabel 4.16 menunjukan bahwa koefisien determinasi yang digunakan untuk melihat kemampuan variabel independen dalam menerangkan variabel dependen, dimana nilai Adjusted Rsquare 0,485 yang dapat diartikan bahwa pengaruh variabel Pengaruh Harga dan Kualitas Produk mempengaruhi Keputusan Pembelian sebesar 48,5\% sedangkan sisanya sebesar $51,5 \%$ dapat dijelaskan oleh variabel lain yang tidak diteliti dalam penelitian ini.

\section{Uji Hipotesis}

Uji Parsial (Uji-t)

Uji ini dilakukan dengan membandingkan nilai t hitung dengan $\mathrm{t}$ tabel. Nilai $\mathrm{t}$ hitung dapat dilihat pada hasil pengolahan data bagian Coefficient. Untuk memperoleh nilai t tabel, dapat dilihat dari tabel T Student, sebagai berikut:

\section{Tabel 12}

Tabel Uji Parsial (Uji-t)

Coefficients $^{\mathrm{a}}$

\begin{tabular}{|c|c|c|c|c|c|c|}
\hline \multirow{2}{*}{\multicolumn{2}{|c|}{ Model }} & \multicolumn{2}{|c|}{ Unstandardized Coefficients } & $\begin{array}{c}\text { Standardized } \\
\text { Coefficients } \\
\end{array}$ & \multirow[b]{2}{*}{$\mathrm{t}$} & \multirow[b]{2}{*}{ Sig. } \\
\hline & & $\mathrm{B}$ & Std. Error & Beta & & \\
\hline \multirow[t]{3}{*}{1} & (Constant) & 10.342 & 4.115 & & 2.513 & .015 \\
\hline & Harga & .460 & .141 & .443 & 3.265 & .002 \\
\hline & Kualitas Produk & .273 & .116 & .319 & 2.349 & .022 \\
\hline
\end{tabular}

a. Dependent Variable: Keputusan Pembelian

Sumber: Diolah dengan SPSS 23,0

Dengan membandingkan nilai t hitung dan $\mathrm{t}$ tabel maka dapat disimpulkan:

1) Variabel Pengaruh Harga dengan $t$ hitung $>$ dari t tabel yaitu $3,265>1,671$ dengan sig $0,002<0,050$ maka $\mathrm{H}_{0}$ ditolak dan $\mathrm{H}_{\mathrm{a}}$ diterima (hipotesis penelitian) diterima, artinya Pengaruh Harga mempunyai Pengaruh yang signifikan terhadap Keputusan Pembelian.

2) Variabel Pengaruh Kualitas Produk dengan t hitung $>$ dari tabel yaitu 2,349 > 1,671 dengan sig $0,022<0,050$ maka $\mathrm{H}_{\mathrm{o}}$ ditolak dan $\mathrm{H}_{\mathrm{a}}$ diterima (hipotesis penelitian) diterima, artinya Pengaruh Kualitas Produk mempunyai Pengaruh yang signifikan terhadap Keputusan Pembelian. 


\section{Uji Simultan (Uji F)}

Uji F digunakan untuk mengetahui, terbukti atau tidak hipotesis pengaruh secara serempak variabel bebas yaitu Pengaruh Harga dan Kualitas Produk pemberian sampel terhadap variabel terikat yaitu Keputusan Pembelian.

\section{Tabel 13 \\ Tabel Uji Simultan (Uji F)}

ANOVA

\begin{tabular}{|ll|r|r|r|r|r|}
\hline Model & & Sum of Squares & \multicolumn{1}{|c|}{$\mathrm{df}$} & Mean Square & F & Sig. \\
\hline 1 & Regression & 791.334 & 2 & 395.667 & 28.735 & $.000^{\mathrm{b}}$ \\
& Residual & 784.849 & 57 & 13.769 & & \\
& Total & 1576.183 & 59 & & & \\
\hline
\end{tabular}

a. Dependent Variable: Keputusan Pembelian

b. Predictors: (Constant), Kualitas Produk, Harga

Sumber: Diolah dengan SPSS 23,0

Berdasarkan data diatas diketahui pengaruh Harga (X1) dan Kualitas Produk (X2) secara simultan terhadap Keputusan Pembelian (Y) adalah sebesar nilai F hitung 28,735 > F tabel 2,77 sedangkan nilai signifikan sebesar $0,000<0,05$ sehingga dapat disimpulkan bahwa $\mathrm{H}_{\mathrm{o}}$ ditolak sedangkan $\mathrm{H}_{\mathrm{a}}$ diterima yang berarti terdapat adanya Pengaruh Harga (X1) dan Kualitas Produk (X2) secara simultan terhadap Keputusan Pembelian (Y).

\section{KESIMPULAN DAN SARAN}

\section{Kesimpulan}

Berdasarkan hasil penelitian dari pengolahan data yang diperoleh dapat ditarik kesimpulan sebagai berikut:

1) Terdapat signifikansi antara Pengaruh Harga (X1) terhadap Keputusan Pembelian (Y) pada Toko Ikan Hias Air Tawar Rahmat Akuarium secara parsial. Hal ini dibuktikan dengan melalui hasil perhitungan yang telah dilakukan pada hasil Uji Hipotesis secara parsial (Uji t) diperoleh dari t hitung lebih besar dari t tabel yaitu 3,265 > 1,671 dengan taraf signifikansi $0,002<0,05$ yang berarti bahwa hipotesis dalam penelitian ini menerima $\mathrm{H}_{\mathrm{a}}$ dan menolak $\mathrm{H}_{\mathrm{o}}$. Pengujian ini secara statistik membuktikan bahwa Pengaruh Harga (X1) berpengaruh secara positif terhadap Keputusan Pembelian (Y).

2) Terdapat signifikansi antara Pengaruh Kualitas Produk (X2) terhadap Keputusan Pembelian (Y) pada Toko Ikan Hias Air Tawar Rahmat Akuarium secara parsial. Hal ini dibuktikan dengan melalui hasil perhitungan yang telah dilakukan pada hasil Uji Hipotesis secara parsial (Uji t) diperoleh dari t hitung lebih besar dari $t$ tabel yaitu 2,349 $<1,671$ dengan taraf signifikansi $0,022<0,05$ yang berarti bahwa hipotesis dalam penelitian ini menerima $\mathrm{H}_{\mathrm{a}}$ dan menolak $\mathrm{H}_{0}$. Pengujian ini secara statistik membuktikan bahwa Pengaruh Kualitas Produk (X2) mempunyai pengaruh positif terhadap Keputusan Pembelian (Y).

3) Terdapat signifikansi antara Pengaruh Harga (X1) dan Kualitas Produk (X2) terhadap Keputusan Pembelian (Y) pada Toko Ikan Hias Air Tawar Rahmat Akuarium secara simultan (Uji F). Menunjukkan bahwa nilai F hitung lebih besar dari $F$ tabel yaitu $28.735>2,76$ dengan taraf signifikansi $0,000<0,05$. Pengujian ini secara statistik membuktikan bahwa Pengaruh Harga (X1) dan Pengaruh Kualitas Produk (X2) mempunyai pengaruh positif terhadap Keputusan Pembelian (Y) secara simultan.

\section{Saran}

Sejalan dengan kesimpulan-kesimpulan yang telah diambil dari penelitian ini, saran-saran yang dapat dikemukakan antara lain: 
1) Dalam menetapkan kebijakan harga pada produknya Toko Ikan Hias Rahmat Akuarium sudah cukup baik sehingga harga dapat lebih kompetitif dibanding dengan pesaingnya dimana tetap dapat mendapatkan keuntungan dari penjualan tersebut. Demi tetap terus mempertahankan harga yang kompetitif ini selayaknya Toko Rahmat Akuarium terus melakukan evaluasi-evaluasi guna untuk menetapkan harga sesuai dengan kualitas produk yang sekompetitif mungkin di kedepannya.

2) Toko Ikan Hias Rahmat Akuarium hendaknya terus memperhatikan kualitas produk baik produk utama yaitu ikan hiasnya serta produk pendukungnya yaitu perlengkapan. Dimana untuk produk utama yaitu ikan hias seyogyanya untuk diperhatikan setiap harinya, sehingga jika ada ikan yang tidak sehat maka dapat segera dipisahkan agar konsumen tidak merasa kecewa, begitupula dengan peralatan pendukungnya untuk mencoba dahulu sebelum konsumen membelinya guna memastikan apakah masih berfungsi dengan semestinya.

3) Untuk tetap mempertahankan pelanggan dan menarik minat konsumen yang baru hendaknya Toko Ikan Hias Rahmat Akuarium memperhatikan faktor-faktor yang lainnya seperti memberikan potongan harga/promosi sehingga akan menarik minat konsumen serta bisa tetap mempertahankan pelanggan yang ada.

\section{DAFTAR PUSTAKA}

Alma, Buchari. 2011. Manajemen pemasaran dan Pemasaran jasa. Cetakan Kesembilan. Alfabeta. Bandung

Fandy, Tjibtono. 2011. Pemasaran Jasa. Bayumedia. Malang

Kotler, Philip. 2010. Manajemen Pemasaran. Edisi 13 Bahasa Indonesia.Jilid 1 dan Erlangga.Jakarta

Kotler,Philip and Gary Armstrong. 2012. Prinsip-prinsip Pemasaran. Edisi 13. Jilid 1. Erlangga. Jakarta

Kotler, Philip, dan Kevin Lane Keller. 2012. Manajemen Pemasaran. Edisi 12. Jilid 2. Terjemahan Bob Sabran, MM. Erlangga. Jakarta

Sugiyono. 2010. Metode penelitian Kuantitatif Kualitatif \& RND. Alfabeta. Bandung

Sumarwan, dan Ujang. 2011.Perilaku Konsumen: Teori dan Penerapannya Dalam Pemasaran. Ghalia Indonesia. Bogor 